\title{
Genetic diversity assessed by microsatellite markers in the amphicarpic species Trifolium polymorphum Poir.
}

\author{
IONARA F. CONTERATO ${ }^{1}$, MARIA TERESA SCHIFINO-WITTMANN ${ }^{2}$, DIVANILDE \\ GUERRA $^{3}$, MIRIAM V. BÜTTOW ${ }^{4}$, MIGUEL DALL' AGNOL ${ }^{2}$ and NAIR DAHMER ${ }^{5}$ \\ ${ }^{1}$ Fundação Estadual de Pesquisa Agropecuária, BR 290, Km 412, 97300-000 São Gabriel, RS, Brazil \\ ${ }^{2}$ Departamento de Plantas Forrageiras e Agrometeorologia, Faculdade de Agronomia, Universidade Federal \\ do Rio Grande do Sul, Avenida Bento Gonçalves, 7712, 91501-970 Porto Alegre, RS, Brazil \\ ${ }^{3}$ Faculdade de Agronomia, Universidade Estadual do Rio Grande do Sul, Rua \\ Cipriano Barata, 47, 98600-000 Três Passos, RS, Brazil \\ ${ }^{4}$ Fundação Estadual de Pesquisa Agropecuária, Distrito Fazenda Souza, s/n, 95100-970 Caxias do Sul, RS, Brazil \\ ${ }^{5}$ Sociedade Educacional Três de Maio, Rua Santa Rosa, 2405, 98910-000 Três de Maio, RS, Brazil
}

Manuscript received on October 9, 2017; accepted for publication on October 24, 2017

\begin{abstract}
Trifolium polymorphum Poir. is an amphicarpic forage legume from southern Brazil, Uruguay, Argentina, Paraguay and Chile. Information on the genetic diversity of natural populations in natural grasslands in southern Brazil is limited. In order to increase the knowledge about this species, an analysis of the genetic diversity was carried out in 10 natural populations of T. polymorphum with the use of 20 microsatellite markers. The expected heterozygosity in T. polymorphum populations ranged from 0.40 to 0.43 , with a mean of 0.42 . A total of 193 alleles were detected with a mean of 9.3 alleles per locus and polymorphic information content (PIC) for these markers of 0.62 to 0.89 with a mean of 0.84 . The grouping based on the Jaccard's coefficient of similarity classified populations, regardless of their regions of origin, into two groups with a mean similarity coefficient of 0.32 , reflecting the high genetic variability of the populations, especially those located in the Campanha phytogeographic region. This information on diversity can be used to plan future germplasm collection strategies for conservation purposes and also for the breeding of the species.
\end{abstract}

Key words: genetic variability, microsatellites, natural grasslands, Pampa biome.

\section{INTRODUCTION}

Trifolium polymorphum Poir., is a stoloniferous perennial legume endemic to southern Brazil, Uruguay, Argentina, Paraguay and Chile (Burkart 1987, Zohary and Heller 1984) and one of the

Correspondence to: Ionara Fátima Conterato

E-mail: ionarafc@yahoo.com.br two amphicarpic species of the genus Trifolium, i.e., capable of producing flowers and aerial and subterranean fruits in the same individual (LevYadun 2000). Amphicarpy can be considered a response to different selection pressures, including herbivory, draught, fire, desiccation, seed predation (Cheplick 1987, Kaul et al. 2000, Kumar et al. 2012). T. polymorphum also has a vegetative 
reproduction through stolons and regrowth of the reserve roots separate from the mother plant (Speroni et al. 2014). The subterranean flowers are obligatory cleistogamous with four to five anthers, while the aerial flowers with 10 anthers (Conterato and Schifino-Wittmann 2014) have been reported as being allogamous, self-compatible and that benefit from pollinators for seed production (Real et al. 2007). The other amphicarpic species of the genus, $T$. argentinense Speg, has been extensively studied in relation to seed dimorphism (Conterato et al. 2010), seed production, morphology, reproductive biology and life strategy (Conterato et al. 2013).

During winter T. polymorphum is an important forage component of natural grasslands of Rio Grande do Sul (between $30^{\circ} \mathrm{S}$ and $34^{\circ} \mathrm{S}$ ) due to its high palatability and good forage quality (Speroni and Izaguirre 2003). However, the loss of large areas of these grasslands in Rio Grande do Sul due to conversion to annual agricultural crops, especially soybean and corn and silviculture (mainly of eucalyptus and pine), and the degradation associated with the invasion of exotic species such as Eragrostis plana Ness (called capim anoni in Brazil) is a major threat to the genetic diversity of this highly biodiverse natural ecosystem that provides soil carbon storage, erosion control, soil water infiltration, pollinator availability and forage production (Pillar et al. 2012). Therefore, conservation strategies to understand patterns of genetic variation within and between populations are crucial to assess the current status of populations (Béjaoui et al. 2011, Corlett 2016) and to establish a collection strategy for the conservation and use of germplasm (Rao and Hodgkin 2002, Whitlock et al. 2016).

Microsatellites, also known as SSR (Simple Sequence Repeats) markers, have gained considerable importance for their many desirable genetic attributes, including hypervariability, broad genomic distribution, co-dominant inheritance, reproducibility, multi-allelic nature and specific chromosomal location (Verma et al. 2015), and for their wide use in analyzing genetic diversity (Dalla Rizza et al. 2007, Conterato et al. 2013, Dugar and Popov 2013, Njung'e et al. 2016, Liang et al. 2007, Sinha et al. 2015, Swift et al. 2016), plant breeding (Islam et al. 2012, Tan et al. 2014), phylogenetic studies (Kang et al. 2015), among others.

With the exception of the studies by Dalla Rizza et al. (2007) and Real et al. (2007), which evaluated the genetic diversity in Uruguayan populations of T. polymorphum with ISSR and SSR molecular markers, respectively, no other study was conducted with this purpose for this species. The objective of this study was to evaluate the genetic diversity in populations of $T$. polymorphum occurring in Rio Grande do Sul, from the germination of aerial seeds.

\section{MATERIALS AND METHODS}

\section{PLANT MATERIAL}

Seeds from ten accessions (naturally occurring populations) of $T$. polymorphum were collected in November or December of 2002, 2005, 2006, 2007, 2008 and 2010 along the species area of distribution in physiographic regions of Rio Grande do Sul in the Pampa and Mata Atlântica (Atlantic Forest) biomes (Table I).The taxonomic vouchers are kept at Herbarium HBEI (Universidade Federal do Pampa, Campus São Gabriel, Brazil) (Table I). In each locality, between 30 and 60 aerial inflorescences with mature legumes were collected in paper bags from at least 15 plants around a ca. $300 \mathrm{~m}^{2}$ area. Afterwards, the legumes of each accessions were opened and the seeds bulked and stored in a refrigerator at the Departamento de Plantas Forrageiras e Agrometeorologia/Faculdade de Agronomia da Universidade Federal do Rio Grande do Sul and later used for molecular analysis. 
TABLE I

Acessions of T. polymorphum analyzed, collector's number, physiographic region and expected heterozigosity.

\begin{tabular}{|c|c|c|c|}
\hline $\begin{array}{c}\text { Acession/ } \\
\text { Place of Collection }\end{array}$ & $\begin{array}{l}\text { Collector's } \\
\text { number }\end{array}$ & $\begin{array}{c}\text { Physiographic } \\
\text { region }\end{array}$ & ${ }^{\mathrm{b}} \mathbf{H Z}$ \\
\hline 01-Caçapava do Sul (30 $\left.30^{\prime} \mathrm{S}, 53^{\circ} 29^{\prime} \mathrm{W}\right)$ & HBEI 1446 & Serra do Sudeste & 0.426 \\
\hline an4-São Jerônimo (29 $57^{\prime}$ S, $51^{\circ}$ 43’ W) & HBEI 1437 & Depressão Central & 0.410 \\
\hline an6-Rio Pardo (29 $\left.59^{\circ} \mathrm{S}, 52^{\circ} 22^{\prime} \mathrm{W}\right)$ & HBEI 1440 & Campanha & 0.424 \\
\hline 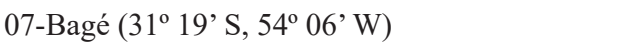 & HBEI 1448 & Campanha & 0.432 \\
\hline 10-Bagé (31º 19’ S, 54º 06’W) & HBEI 1439 & Campanha & 0.411 \\
\hline 12-Pelotas ( $\left.31^{\circ} 46^{\prime} \mathrm{S}, 52^{\circ} 20^{\prime} \mathrm{W}\right)$ & HBEI 1445 & Encosta do Sudeste & 0.434 \\
\hline 17-Eldorado do Sul $\left(30^{\circ} 05^{\prime} \mathrm{S}, 51^{\circ} 36^{\prime} \mathrm{W}\right)$ & HBEI 1442 & Depressão Central & 0.413 \\
\hline 18-Santana do Livramento ( $\left.30^{\circ} 53^{\prime} \mathrm{S}, 55^{\circ} 31^{\prime} \mathrm{W}\right)$ & HBEI 1441 & Campanha & 0.434 \\
\hline 20-Pinheiro Machado ( $\left.31^{\circ} 34^{\prime} \mathrm{S}, 5^{\circ} 22^{\prime} \mathrm{W}\right)$ & HBEI 1447 & Campanha & 0.429 \\
\hline 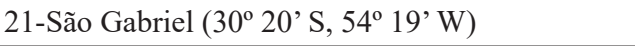 & HBEI 1449 & Campanha & 0.405 \\
\hline Average & & & 0.422 \\
\hline
\end{tabular}

a 04-São Jerônimo and 06-Rio Pardo are accessions from Mata Atlântica (Atlantic Forest) biome and other accessions are from Pampa biome. The values cited of latitude (S) and longitude (W) refers to the municipality where the collection was carried and not to the collection site itself.

${ }^{b}$ Expected heterozigosity.

\section{MOLECULAR ANALYSIS}

In April 2010, 15 aerial seeds of each accession were scarified with sandpaper and germinated in petri dishes with moistened filter paper. The germinated seedlings were transferred to 200 $\mathrm{ml}$ capacity plastic cups filled with commercial substrate and in August 2010, 10 plants were transferred to plastic boxes $(34 \mathrm{~cm} \times 14 \mathrm{~cm} \times 11.5$ $\mathrm{cm}$ ) filled with commercial substrate, one plant per box in an open area. Two plants of each population did not persist and the experiment was conducted with eight plants of each population. The total genomic DNA of each sample (100-150 ng) was extracted from a bulk of young leaves of eight plants per accession, following Doyle and Doyle (1990) protocol with slight modifications. DNA concentration and quality were evaluated in $1 \%$ agarose gel, using 100 and $500 \mathrm{ng}$ fago $\lambda$ DNA as standard.

Five microsatellite (SSR) primers developed for T. repens L. and 19 primers developed for Lotus japonicus L. (Regel) Larsen were tested and, from these, 20 were selected to be used plants grown from aerial seeds. PCR reactions were prepared in a final volume of $6 \mu \mathrm{L}$ per reaction, containing 2 $\mu \mathrm{L}$ of the work DNA solution $(25 \mathrm{ng} / \mu \mathrm{L}), 1 \mu \mathrm{L}$ of PCR 10X buffer, $0.6 \mu \mathrm{L}$ of $\mathrm{MgCl}_{2}(50 \mathrm{nM}), 0.8$ $\mu \mathrm{L}$ of DNTP mix containing $2.5 \mathrm{mM}$ of each of the four nucleotides, $0.6 \mu \mathrm{L}$ of the forward primer $(10 \mu \mathrm{M}), 0.6 \mu \mathrm{L}$ of the reverse primer $(10 \mu \mathrm{M})$, $0.2 \mu \mathrm{L}$ of $T a q$ polymerase Quiagen $(5 \mathrm{U} / \mu \mathrm{L})$ and Miliq sterilized water to complete the volume. PCR conditions followed Dias et al. (2008) with the following modifications: initial denaturation at $94^{\circ} \mathrm{C}$ for $5 \mathrm{~min}$, followed by seven cycles of $1 \mathrm{~min}$ at $94^{\circ} \mathrm{C}, 1 \mathrm{~min}$ at $61^{\circ} \mathrm{C}, 1 \mathrm{~min}$ at $72^{\circ} \mathrm{C}$, and annealing temperature reduction of $1^{\circ} \mathrm{C}$ per cycle, followed by 25 cycles of $1 \mathrm{~min}$ at $94^{\circ} \mathrm{C}, 1 \mathrm{~min}$ at $55^{\circ} \mathrm{C}$ and 1 min at $72^{\circ} \mathrm{C}$ and six cycles of 45 seconds at $94^{\circ} \mathrm{C}$, 45 seconds at $54^{\circ} \mathrm{C}$ and 45 seconds at $72^{\circ} \mathrm{C}$ and a final extension for 8 minutes at $72^{\circ} \mathrm{C}$ and storage at $7^{\circ} \mathrm{C}$. The amplification products were separated in a 3\% high resolution agarose gel (Agarose 1000) stained with $0.08 \mu \mathrm{L} / \mathrm{mL}$ ethidium bromide (10 $\mathrm{mg} / \mathrm{mL}$ ) and immersed in TBE $1 \mathrm{X}$ buffer under an electrophoretic current of $96 \mathrm{~V}$ for approximately 2 
hours. After electrophoresis, the gel was visualized in an ultraviolet light (wavelength of $260 \mathrm{~nm}$ ) and photographed in order to compare the samples fragments with a 100 base pair (bp) ladder, using the Kodak EDAS 290 (Electrophoresis Documentation and Analysis System) program.

The dendrogram of genetic similarity among accessions was obtained from the similarity coefficients using the UPGMA (Unweighted PairGroup Method Using an Arithmetic Average). Cluster analysis was performed using the Numerical Taxonomy and Multivariate Analysis System NTSYSpc program version 2.1 (Rohlf 2001) and the similarity matrix constructed with Jaccard's coefficient. The total number of alleles per locus (A), the allelic frequencies and the Polymorphism Information Content (PIC) for each locus (PICi $=$ $1-\sum \mathrm{Pi}$, where Pi is the frequency of allele I band) were calculated. The expected heterozygosity (HZ) of each identified band was calculated using the following formula: $H Z i=1-(+)$, where $\mathrm{P}_{i p}$ and $\mathrm{P}_{i a}$ are the frequency of presence and absence of the $i$ th band (Isobe et al. 2013). The individuals of each population were assessed in bulk; therefore, the mean $H Z$ value of identified bands generated by a marker in a population was substituted for the $H Z$ of each population.

\section{RESULTS AND DISCUSSION}

The level of expected heterozygosity is a measure of diversity that provides information on the proportion of different alleles in populations (Pagnotta et al. 2011). The values of expected heterozygosity among the accessions (HZ) ranged from 0.40 (21-São Gabriel accession) to 0.43 (12-Pelotas and 18-Santana do Livramento accessions), with a mean of 0.42 (Table I), showing a moderate differentiation between the populations of T. polymorphum for the analyzed loci. Based on the literature, the expected heterozygosity for species of the Trifolium does not contemplate $T$. polymorphum, which makes the present results important, since it complements information on the species. This data differs from that obtained in cultivars of $T$. pratense by Dugar and Popov (2013) where the expected heterozygosity ranged from 0.22 to 0.80 (mean 0.70) with the use of SSR, and by Pagnotta et al. (2011) who found expected heterozygosity between 0.18 and 0.43 (mean 0.31 ) with the use of amplified fragment length polymorphism (AFLP) markers in Italian red clover genotypes, including local varieties, natural populations and ancient cultivars of the species.

Amplification of the 20 SSR primers in the 10 accessions of $T$. polymorphum resulted in a total of 193 alleles, ranging in size from 50 to 420 base pairs. The number of alleles per locus ranged from a minimum of seven (SSR TM0080) to a maximum of 12 (SSR TM0070), with a mean of 9.3 alleles per locus (Table II), which are comparable to previous studies in the amphicarpic T. argentinense (8.90, Conterato et al. 2013), and in the allogamous Trifolium pratense L. (11.1, Dias et al. 2008 and 8.70, Dugar and Popov 2013). In Uruguayan populations of T. polymorphum, Real et al. (2007), using only five SSRs, found from three to nine alleles per locus. According to Shiferaw et al. (2012), the number of alleles detected per marker and the level of genetic diversity depend on the number and origin of the genotypes analyzed and it is not easy to compare the level of diversity between different studies. However, both studies confirm the importance of SSR to access diversity in T. polymorphum.

The PIC values, which reflect allelic diversity and frequency, were high, ranging from 0.62 (SSR TM0118) to 0.89 (SSR prs461, SSR TM0180, SSR TM0065 and SSR TM0406), with a mean of 0.84 (Table II), similar to the PIC variation between 0.52 to 0.86 in Uruguayan populations and as expected for a highly heterogeneous cross-pollinated species such as T. polymorphum (Real et al. 2007). Similar results were found for the $T$. argentinense, with 
TABLE II

Characteristics of the 20 microsatellite marker used for T. polymorphum.

\begin{tabular}{|c|c|c|c|c|}
\hline Primer & Primer sequence & $\begin{array}{l}\text { Alelle size } \\
(\mathrm{pb})\end{array}$ & $\begin{array}{c}\text { Alelle } \\
\text { number }\end{array}$ & PIC \\
\hline a'TRSSRAXX31 & $\begin{array}{c}\text { F: TCTGTTTTGTTGGCCATGC } \\
\text { R: TTGCAAAGTGTTTGGAAGGA }\end{array}$ & $150-400$ & 11 & 0.80 \\
\hline aprs461 & $\begin{array}{l}\text { F: ACCTTCCGATATCCCAAACC } \\
\text { R: ATGGTGCGTTTGGAGATAGC }\end{array}$ & $80-380$ & 10 & 0.89 \\
\hline aprs 582 & $\begin{array}{c}\text { F: CCGGTTCGATTCAACAAGTT } \\
\text { R: CTGCAGATCCAGTAATGATTTCC }\end{array}$ & $100-390$ & 08 & 0.84 \\
\hline aprs 612 & $\begin{array}{l}\text { F: TTGAACTAGTCGTTGGATGGG } \\
\text { R: GAGAGGGTTTCAGGAACATACG }\end{array}$ & $100-380$ & 10 & 0.85 \\
\hline${ }^{\mathrm{b}} \mathrm{TM} 0095$ & $\begin{array}{l}\text { F: CTTGTGGTTTTCTTCCCGAC } \\
\text { R: GGGACAAAAGAAAATAACGC }\end{array}$ & $90-420$ & 09 & 0.88 \\
\hline${ }^{\mathrm{b}} \mathrm{TM} 0180$ & $\begin{array}{c}\text { F: CAGTTATTTAGGAACGGAGG } \\
\text { R: AAACAAACAGTAAGTGTCTCATC }\end{array}$ & $70-400$ & 11 & 0.89 \\
\hline${ }^{\mathrm{b}} \mathrm{TM} 0817$ & $\begin{array}{l}\text { F: TTGCTCATGTGAGAAAGAAC } \\
\text { R: GCTTTAAAATGACGTCCTAATC }\end{array}$ & $70-420$ & 08 & 0.86 \\
\hline${ }^{\mathrm{b}} \mathrm{TM} 0118$ & $\begin{array}{l}\text { F: TGCAATTTACTCTTTATATTTCG } \\
\text { R: TCCAATTCAAATTATTTTATAGAG }\end{array}$ & $70-400$ & 11 & 0.62 \\
\hline${ }^{\mathrm{b}} \mathrm{TM} 0314$ & $\begin{array}{c}\text { F: TGTGATTAGTGATTAGAAAGTGAG } \\
\text { R: TTTGACCAAACTTCCTTCAC }\end{array}$ & $110-420$ & 08 & 0.85 \\
\hline${ }^{\mathrm{b}} \mathrm{TM} 0056$ & $\begin{array}{l}\text { F: CATTAGAATATTGAATGCACC } \\
\text { R: TCTCTTCTCTCTGTTATTTATAGC }\end{array}$ & $70-400$ & 10 & 0.85 \\
\hline${ }^{\mathrm{b}} \mathrm{TM} 0436$ & $\begin{array}{l}\text { F: ATGTTGTCTGTGTGTCTGTG } \\
\text { R: AAATTGATTGAAAAGGGGTG }\end{array}$ & $160-400$ & 09 & 0,86 \\
\hline${ }^{\mathrm{b}} \mathrm{TM} 0771$ & $\begin{array}{l}\text { F: CACTTCCTTTGAGAGCAGTC } \\
\text { R: GTTCCCTTGAAAATTGAATG }\end{array}$ & $50-400$ & 10 & 0.88 \\
\hline${ }^{\mathrm{b}} \mathrm{TM} 0070$ & $\begin{array}{l}\text { F: CTTAACAAAAGTCTGGGGTG } \\
\text { R: GAATGTGTGGTAGCTTGTTG }\end{array}$ & $80-400$ & 12 & 0.88 \\
\hline${ }^{\mathrm{b}} \mathrm{TM} 0080$ & $\begin{array}{c}\text { F: AACAAAATACTAAACTATAGCAAAG } \\
\text { R: CGTCCCACAACTCTCTTTAC }\end{array}$ & $100-400$ & 07 & 0.72 \\
\hline${ }^{\mathrm{b}} \mathrm{TM} 0654$ & $\begin{array}{l}\text { F: TCAGTTGAGACCTCAAAATC } \\
\text { R: TCCTGATAGAAGTGATTTGG }\end{array}$ & $80-400$ & 10 & 0.87 \\
\hline${ }^{\mathrm{b}} \mathrm{TM} 0065$ & $\begin{array}{c}\text { F: AATGCTAGTTAAGCGCTCTC } \\
\text { R: CCCAAAGGTCTATAATTATAAGG }\end{array}$ & $100-400$ & 11 & 0.89 \\
\hline${ }^{\mathrm{b}} \mathrm{TM} 0076$ & $\begin{array}{c}\text { F: TCAAATGTGATGAGTGACATAC } \\
\text { R: AAAACATGTAGCTAAGAAACTAAAA }\end{array}$ & $150-400$ & 08 & 0.88 \\
\hline${ }^{\mathrm{b}} \mathrm{TM} 0059$ & $\begin{array}{c}\text { F: TCCTTCATTCATTCATAACC } \\
\text { R: TGAGAAGAGAATGAAAAGCG }\end{array}$ & $100-400$ & 09 & 0.82 \\
\hline${ }^{\mathrm{b}} \mathrm{TM} 0406$ & $\begin{array}{l}\text { F: CAGACAGAGAAAAGGGTCAG } \\
\text { R: TGCATCTTCAGTTGCTCTTG }\end{array}$ & $80-400$ & 11 & 0.89 \\
\hline${ }^{\mathrm{b}} \mathrm{TM} 0711$ & $\begin{array}{c}\text { F: CCTAAGATCATTTAGACAAAACTC } \\
\text { R: AAAGATGTTCTCTTGGGTTG }\end{array}$ & $100-400$ & 10 & 0.84 \\
\hline Total average & & & 193(9.3) & 0.84 \\
\hline
\end{tabular}

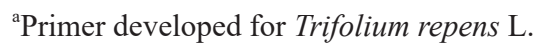

${ }^{\mathrm{b}}$ Primer developed for Lotus japonicus (Regel) Larsen. 
PIC values between 0.66 and 0.93 (Conterato et al. 2013), the Trifolium riograndense Speg, between 0.48 and 0.80 (Conterato et al. 2012) and T. pretense, between 0.70 and 0.86 (Dias et al. 2008). In T. polymorphum plants grown from aerial seeds, Real et al. (2007) identified a greater 'inter-patch' than 'intra-patch' variability with the use of SSR, explaining the high polymorphism between populations by cross-pollination aerial seed dispersal, and the low intra-patch variability by vegetative propagation and underground seeds. However, in this study only plants grown from aerial seeds were analyzed.

The similarity between the accessions ranged from 0.16 to 0.56 with a mean of 0.32 (Fig. 1), reflecting the high genetic variability present in the species, even with the substitution by crops of almost $54 \%$ of the original area of the Pampa biome (MMA 2012), and remaining only $12.5 \%$ of the original area of the Atlantic Forest biome (SOS Mata Atlântica 2014). Real et al. (2008) also found a high morphological variation for the leaf mark, leaf margin, central leaflet length, hairiness, number of stolons and plant size for T. polymorphum. The results of genetic diversity of the present work are similar to those found by Conterato et al. (2012) in T. riograndense, but distinct from the coefficient of similarity between 0.50 and 0.90 observed in T. pratense populations by Ahsyee et al. (2014). The co-expressed correlation coefficient of the dendrogram (Fig. 1) was 0.94, indicating a good fit between the original distance matrix and the graphical distance. The UPGMA grouping of genetic distance resulted in two groups using the mean similarity of 0.32 as a cut point: group 1 (04São Jerônimo, 17-Eldorado do Sul, 12-Pelotas,

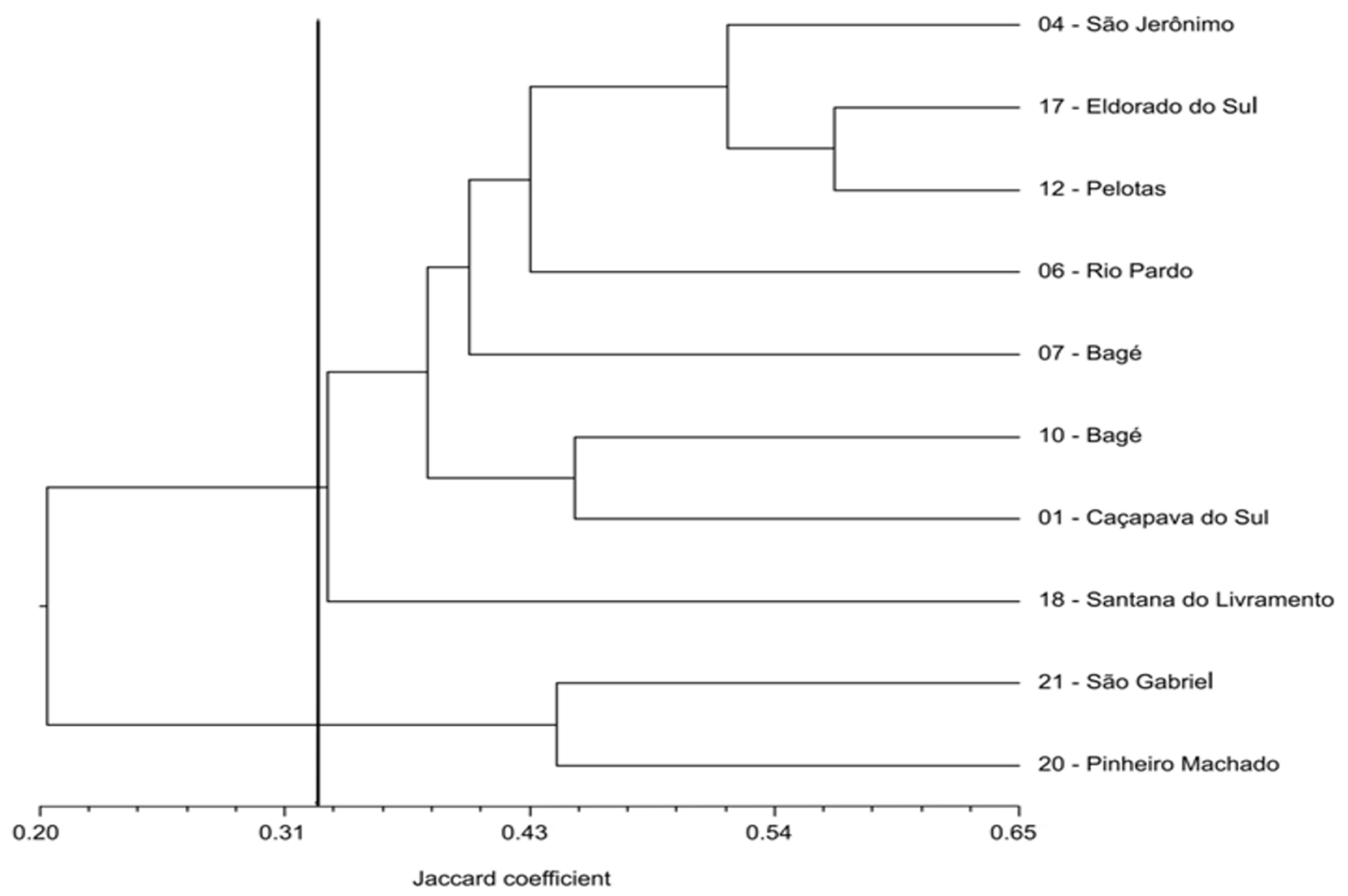

Figure 1 - Dendrogram of 10 T. polymorphum accessions revealed by UPGMA cluster analysis based on SSR markers data using Jaccard's similarity coefficient. 
06-Rio Pardo, 07-Bagé, 10-Bagé, 01-Caçapava do Sul and 18-Santana do Livramento accessions) and group 2 (21-São Gabriel and 20-Pinheiro Machado accessions).

In group 1, the subgroup among the 04-São Jerônimo, 17-Eldorado do Sul and 12-Pelotas accessions does not reflect its geographical origin. Acessions 04-São Jerônimo and 17-Eldorado do Sul, are both municipalities in the physiographic region of the Central Depression showed an average similarity of about $50 \%$ (Fig. 1), while the 17-Eldorado do Sul and 12-Pelotas accessions, distant about $270 \mathrm{~km}$ from each other and belonging to the Central Depression and Sudeste Encosta regions, respectively, were the most similar (about 57\% similarity), a result similar to that of the 10-Bagé and 01-Caçapava do Sul subgroup. The 10-Bagé and 07-Bagé accessions, however, did not remain in the same subgroup (Fig. 1), suggesting that the diversity can be high even in geographically close places. A similar result in group 1 was also observed among the 07-Bagé, 18-Santana do Livramento and 06-Rio Pardo accessions, reflecting the high diversity of T. polymorphumin the physiographic region of the Campanha. In group 2 the 21-São Gabriel and 20-Pinheiro Machado accessions were grouped according to the region of origin.

No well-defined relation between genetic diversity assessed by SSR and geographic origin can be established in the present study (Fig. 1), the same being found by Conterato et al. (2012) for T. riograndense and by Ahsyee et al. (2014) for red clover ( $T$. pratense). In sorghum, Gerrano et al. (2014) found some relation between genetic diversity and geographic origin, and in common beans the relation between the majority of genotypes and the origin of cultivation were strongly correlated (Zargar et al. 2016). The low genetic similarity observed between the accessions of $T$. polymorphum can be a reflection of the contrasting ecogeographic location, absence of gene flow due to the distance between the populations, plus the absence of seed dispersion, low fruit yield, with values ranging from 0.6 to 12 (Speroni and Izaguirre 2003), as well as the high morphological variation naturally present in the species (Zohary and Heller 1984, Real et al. 2007).

The high genetic diversity observed in $T$. polymorphum populations in all phytogeographic regions of Rio Grande do Sul increases the genetic knowledge on this important amphicarpic species of the natural grasslands of Rio Grande do Sul. This information can be used as a tool to plan future collection strategies of this important forage germplasm for conservation purposes and also for the purpose of the species breeding.

\section{ACKNOWLEDGMENTS}

The authors thank the Conselho Nacional de Desenvolvimento Científico e Tecnológico (CNPq, Brazil) for the financial support.

\section{REFERENCES}

AHSYEE RS, VASILJEVIC S, CALIC I, ZORIC M, KARAGIC D AND ŠURLAN-MOMIROVIC G. 2014. Genetic diversity in red clover (Trifolium pratense L.) using ssr markers. Genetika 46: 949-961.

BÉJAOUI A, BOULILA A, MESSAOOUD C AND BOUSSAID M. 2011. Population genetic structure of Tunisian Hypericum humifusum L. assessed by RAPD markers. Biologia 66: 1-8.

BURKART A. 1987. Flora ilustrada de Entre Rios. Buenos Aires: Colección Científica del INTA, 763 p.

CHEPLICK GP. 1987. The ecology of amphicarpic plants. Trends Ecol Evol 2: 97-101.

CONTERATO IF, DALL'AGNOL M, SCHIFINOWITTMANN MT AND JANKE A. 2012. Microsatellite diversity and chromosome number in natural populations of Trifolium riograndense Burkart. Sci Agric 69: 114-118.

CONTERATO IF AND SCHIFINO-WITTMANN MT. 2014. Estratégias reprodutivas da espécie anficárpica Trifolium polymorphum Poir. Enciclopédia Biosfera 10: 2213-2222.

CONTERATO IF, SCHIFINO-WITTMANN MT AND DALL'AGNOL M. 2010. Seed dimorphism, chromosome number and karyotype of the amphicarpic species Trifolium argentinense Speg. Genet Resour Crop Evol 57: 727-731. 
CONTERATO IF, SCHIFINO-WITTMANN MT, GUERRA D AND DALL'AGNOL M. 2013. Amphicarpy in Trifolium argentinense: morphological characterization, seed production, reproductive behavior and life strategy. Aust J Bot 61: 119-127.

CORLETT RT. 2016. Plant diversity in a changing world: Status, trends, and conservation needs. Plant Diversity 38: 10-16.

DALLA RIZZA M, REAL D, REYNO R, PORRO V, BURGUENO J, ERRICO E AND QUESENBERRY KH. 2007. Genetic diversity and ADN content of three South American and three Eurasiatic Trifolium species. Genet Mol Biol 30: 1118-1124.

DIAS PMB, JULIER B, SAMPOUX, JP, BARRE P AND DALL'AGNOL M. 2008. Genetic diversity in red clover (Trifolium pratense L.) revealed by morphological and microsatellite (SSR) markers. Euphytica 160: 189-205.

DOYLE JJ AND DOYLE JL. 1990. Isolation of plant DNA from fresh tissue. Focus 12: 13-15.

DUGAR YN AND POPOV VN. 2013. Genetic structure and diversity of Ukrainian red clover cultivars revealed by microsatellite markers. O J Gen 3: 235-242.

GERRANO AS, LABUSCHAGNE MT, BILJON AV AND SHARGIE NG. 2014. Genetic diversity assessment in sorghum accessions using qualitative morphological and amplified fragment length polymorphism markers. Sci Agric 71: 345-355.

ISLAM S, HAQUE MS, EMON RM, ISLAM MM AND BEGUM SN. 2012. Molecular characterization of wheat (Triticum aestivum L.) genotypes through SSR markers. Bangladesh J Agril Res 37: 389-398.

ISOBE SN ET AL. 2013. Construction of an integrated high density simple sequence repeat linkage map in cultivated strawberry (Fragaria $x$ ananassa) and its applicability. DNA Res 20: 79-92.

KANG JY, LU JJ, QIU S, CHEN Z, LIU J AND WANG H. 2015. Dendrobium SSR markers play a good role in genetic diversity and phylogenetic analysis of Orchidaceae species. Sci Hortic 183: 160-166.

KAUL V, KOUL AK AND SHARMA MC. 2000. The underground flower. Curr Sci 78: 39-44.

KUMAR PS, LAWN RJ AND BIELIG LM. 2012. Comparative studies on reproductive structures in four amphicarpic tropical Phaseoleae legumes. Crop Pasture Sci 63: 570581.

LEV-YADUN S. 2000. Why are underground flowering and fruiting more common in Israel than anywhere else in the world? Curr Sci 79: 289.

LIANG ZC, YANG JI AND RAO GY. 2007. Development of microsatellite markers in an amphicarpic species, Amphicarpaea edgeworthii Benth. (Leguminosae). Mol Ecol 7: 863-865.
MMA - MINISTÉRIO DO MEIO AMBIENTE. 2012. Disponível em: http://www.mma.gov.br/informma/ item/7455-mma-divulga-dados-do-monitoramentodo desmatamento-de-tres-biomas. Acessado em 16 de Setembro de 2016.

NJUNG'E V, DESHPANDE S, SIAMBI M, JONES R, SILIM S AND DE VILLIERS S. 2016. SSR genetic diversity assessment of popular pigeonpea varieties in Malawi reveals unique fingerprints. Electron J Biotechnol 21: 6571.

PAGNOTTA MA, ANNICCHIARICO P, FARINA A AND PROIETTI S. 2011. Characterizing the molecular and morphophysiological diversity of Italian red clover. Euphytica 179: 393-404.

PILLAR VD, TORNQUIST CG AND BAYER C. 2012. The southern Brazilian grassland biome: soil carbon stocks, fluxes of greenhouse gases and some options for mitigation. Braz J Biol 72: 673-681.

RAO VR AND HODGKIN T. 2002. Genetic diversity and conservation and utilization of plant genetic resources. Plant Cell Tiss Org 68: 1-19.

REAL D, DALLA RIZZA M, REYNO R AND QUESENBERRY KH. 2007. Breeding system of the aerial flowers in an amphicarpic clover species: Trifolium polymorphum. Crop Sci 47: 1401-1406.

ROHLF FJ. 2001. Ntsys PC numerical taxonomy and multivariate analysis system: version 2.1. Exeter Software, New York.

SHIFERAW E, PÈ ME, PORCEDDU E AND PONNAIAH M. 2012. Exploring the genetic diversity of Ethiopian grass pea (Lathyrus sativus L.) using EST-SSR markers. Mol Breeding 30: 789-797.

SINHA P, ISLAM MA, NEGI MS AND TRIPATHI SB. 2015. Estimation of outcrossing rates in interspecific backcross plants of Jatropha curcas (L.) using AFLP and SSR markers. Physiol Mol Biol Plants 21: 605-609.

SOS MATA ATLÂNTICA. 2014. Divulgados novos dados sobre o desmatamento da Mata Atlântica. Disponível em: https://www.sosma.org.br. Acessado em 14 de Setembro de 2016.

SPERONI G AND IZAGUIRRE P. 2003. Características biológicas de la leguminosa nativa promissora forrajera Trifolium polymorphum Poir. (Fabaceae, Faboideae). Agrociencia 7: 68-76.

SPERONI G, IZAGUIRRE P, BERNARDELLO G AND FRANCO J. 2014. Reproductive versatility in legumes: the case of amphicarpy in Trifolium polymorphum. Pl Biol 16: 690-696.

SWIFT JF, SMITH SA, MONGES ES, BASSÜNER B AND EDWARDS CE. 2016. Analysis of mating system and genetic structure in the endangered, amphicarpic plant, Lewton's polygala (Polygala lewtonii). Conserv Genet 16: 1269-1284. 
TAN C, WU Y, TALIAFERRO CH, BELL GE, MARTIN DL AND SMITH MW. 2014. Development and characterization of genomic SSR markers in Cynodon transvaalensis Burtt-Davy. Mol Genet Genomics 289: 523-531.

VERMA P, CHANDRA A, ROY AK, MALAVIYA DR, KAUSHAL P, PANDEY D AND BHATIA S. 2015. Development, characterization and cross-species transferability of genomic SSR markers in berseem (Trifolium alexandrinum L.), an important multi-cut annual forage legume. Mol Breeding 35: 1-14.
WHITLOCK R, HIPPERSON H, THOMPSON DBA, BUTLIN RK AND BURKE T. 2016. Consequences of in-situ strategies for the conservation of plant genetic diversity. Biol Conserv 203: 134-142.

ZARGAR SM, FARHAT S, MAHAJAN R, BHAKHRI A AND SHARMA A. 2016. Unraveling the efficiency of RAPD and SSR markers in diversity analysis and population structure estimation in common bean. Saudi J Biol Sci 23: 139-149.

ZOHARY M AND HELLER D. 1984. The Genus Trifolium L. Jerusalem: The Israel Academy of Sciences and Humanities, 606 p. 